\title{
Children's rights and violence: A case analysis at a Swedish boarding school
}

\author{
Guadalupe Francia* \\ Uppsala University, Sweden
}

\section{Silvia Edling*}

University of Gävle, Sweden

\begin{abstract}
Drawing on the Convention on the Rights of the Child, the article highlights various conceptions of violence at a Swedish boarding school and is based on a critical discourse analysis of different educational and media documents. The investigation indicates that ambitions to protect children from violence need to overcome the dichotomy of private and public in order to protect children affected by violence in the borderland between the private and public spheres.
\end{abstract}

\section{Keywords}

Boarding schools, children's rights, discourse, norms, socialization, violence

\section{Introduction}

Drawing on the Convention on the Rights of the Child (CRC), the article aims to highlight various actors' interpretations of reported violence at a boarding school in Sweden. The desire to protect children from violence is clearly formulated in the Convention. For example, the right of children to be protected from

... all forms of physical or mental violence, injury or abuse, neglect or negligent treatment, maltreatment or exploitation, including sexual abuse, while in the care of parent(s), legal guardian(s) or any other person who has the care of the child

\section{*Contributed equally to this article}

\section{Corresponding author:}

Guadalupe Francia, Associate professor/senior lecturer in pedagogy, Department of Education, Uppsala University, Box 2136, SE- 75002 Uppsala, Sweden.

Email: guadalupe.francia@edu.uu.se 
is clearly stated in Article 19 of the CRC, which was ratified by Sweden in 1989 (United Nations, 1989). The right of children not to be subjected to various forms of violence is also emphasized in other international treaties signed and/or ratified by the Swedish state (the Universal Declaration of Human Rights, the European Convention of Human Rights, the Convention on the Rights of Persons with Disabilities 2010, the Treaty of Lisbon). In order to assure this right, the Swedish legal framework (Prop., 2009/10:232) stipulates that the subjection of children to violence should be avoided at all cost.

In this study, the word violence is used in a broad sense to cover the numerous situations in which people are at risk of being physically and psychologically damaged (Hamby and Grych, 2013), such as in cases of discrimination, bullying, violation, or harassment (cf. Greeff and Grobler, 2008; Parkes, 2007). Although the ambition to oppose and counteract violence in schools has increased in Sweden through the introduction of the Discrimination Act (SFS, 2008:567) and the paragraph regarding the treatment of others in the Education Act (SFS, 2010:800, paragraph 6), several international investigations have pointed to the difficulties of counteracting violence at boarding schools due to their specific features and the vague borderline between the children's public and private spheres (Benelli, 2002; Garcia and Monteoliva, 2000; Zindi, 1994). Hence, although violence can be found in any school, the particular features of boarding schools, where the division between school and private life is fuzzy, make them an interesting study.

Addressing violence at boarding schools has mainly been done from a psychological perspective in terms of highlighting behavioral difficulties as the roots of violence (Pfeiffer and Pinquart, 2014) and/or the trauma that victims of violence suffer. The boarding school syndrome refers to the phenomenon of young children being separated from their parents and placed in an environment characterized by violence and insecurity, which can create long-term trauma (Partridge, 2007, 2012, Schaverien, 2011; Standish, 2011). However, the multi-layered features of violence indicate that research on violence cannot simply be reduced to individual experience and behavior but also needs to take into account the intersecting web of social perceptions and norms (Epp and Watkinson, 1997; Kumashiro and Ngo, 2007). Against this background, the article aims to contribute to an exploration of the patterns of violence against children by analyzing various actors' conceptions of violent cases at a Swedish boarding school which have been brought to the attention of the Swedish Schools Inspectorate (SSI). The following questions are asked:

1. How do the different actors describe the violent acts at the boarding school?

2. Which intertexts are presented/referred to in the school's construction of violent acts?

3. How can these descriptions be explained in a broader discussion about the enactment of policies to protect the right of children not to be subjected to violence?

To illustrate the different conceptions of violence in a boarding school, this article analyzes the discourses of two serious cases of violence reported in a boarding school setting in 2011 and 2013. In the first section of the article, an overview of the policy 
documents, theory, previous research, and methodology relevant to the study in question will be presented. This is followed by an analysis of various texts and various actors' descriptions of how they view the violent acts that occurred at the boarding school in question. Finally, the article ends with a discussion of how the findings can be understood in relation to the responsibilities of educational institutions to protect the right of children not to be exposed to various forms of violence.

\section{Theoretical starting points}

In this section, we will look at the empirical material through a theoretical lens. We begin by describing childhood as a socially constructed space. This is followed by a theoretical argumentation about how violence is addressed in the article. Previous research on violence at boarding schools is used to support this.

\section{The child or childhood as a socially constructed space}

Starting from the theoretical framework of childhood as a socially contracted space determined by interactions of social, cultural, and political forces (James and James, 2004, 2005), this article argues the need to pay attention to historical and social contexts in the analysis of child violence at boarding schools. In our view, the choice of this particular theoretical framework makes it possible to understand the various positions taken by children as both objects and subjects. In this way of reasoning, children are regarded as "social agents in that they shape those roles, both as individuals and as a collectivity, and they can create new ones that alter the social space of childhood to be inherited by the next generation" (James and James, 2004: 213, 214).

In the context of this theoretical framework, where childhood is regarded as a socially contracted space, Bentley's distinction of the liberal and republican conception of childhood is especially relevant for the study of violence against and by children because it offers analytical instruments with which to understand the different actors' descriptions of violence at boarding schools. According to Bentley (2005), the liberal conception "regards children as part of families, and so covered by a mantle of privacy which precludes the interference of the state" (p. 118). In contrast, the republican conception considers children as "future citizens who are first and foremost members of their society and so must be groomed to be fit to participate in that society" (Bentley, 2005: 118). Therefore, this conception accepts "a degree of state or communal responsibility for their [children's] upbringing and education, which could imply a decrease in parental authority" (Bentley, 2005: 118). However, the vision of children as "holders of rights" (Bentley, 2005: 118) expressed in the republican conception pleads for a dialogue between private and public matters that are seen as dialectically interconnected. Against this background, there is reason to be attentive to how public and private spheres are played out in different actors' conceptions of children's violence in an educational context.

In line with Englund (1993), our study uses public and private spheres as theoretical concepts to analyze the different standpoints on violence at a boarding school. According to Englund (1993), when the education of the child is considered to be for the public good, it is the public sector that has the ultimate responsibility for the education of all 
citizens. By considering education as a social issue, the "public good" discourse legitimizes the interventions of the state to forcefully encourage general equality-based schooling for all citizens. In contrast, if education is considered to be a private good, it becomes a family issue, which implies that the family has the right to view children's schooling as a social investment that reflects the family's values and needs (Englund, 1993). The question of whether violence is to be viewed as a public or private issue has been debated in various contexts and highlights who should be regarded as responsible for the violence that takes place in interpersonal relations. Is it solely the individual or should the government be involved? (see, for example, Araujo et al., 2000). It should be emphasized that in this article, the two concepts should not be regarded as either/or categories, but as interdependent concepts under constant negotiation in relation to specific educational purposes.

\section{The systemic violence perspective}

We applied the notion of systemic violence to approach the recurring events of violence reported at the boarding school of our study, Lundsberg School. Following Epp and Watkinson (1997), we consider “... systemic violence as any institutionalized practice or procedure that adversely impacts on disadvantaged individuals or groups by burdening them psychologically, mentally, culturally, spiritually, economically or psychically" (pp. 4-5). The violence that materializes as a consequence of these structures does not necessarily have to do with ill will, as in deliberately wanting to do harm. On the contrary, what characterizes these acts is that they appear normal and harmless at the same time as they occasion various forms of violence (Epp and Watkinson, 1997: 6), such as comrade oppression, which is a term used for a repeated violent act. Systemic violence is thus a culture of violence that is embedded in the school as an institution and is expressed by people's (teachers', leaders', administrators', pupils', and students') ways of acting: endorsed ideals, talking, gestures, choice of subject content, rule-making, and so forth (cf. Gillander Gådin et al., 2013). The focus on how the flow of (power) relations in everyday school life affects conditions for securing children's rights is an important and often neglected aspect of research on these rights, where the focus instead tends to be on disseminating information in education (cf. Quennerstedt, 2011).

The systemic violence perspective is also present in Poynting and Donaldson's (2005) research on violence in independent boarding schools for boys in Australia as an important part of the construction process of the ruling-class masculinity ideal. According to this research, the socialization of boys from wealthy families involves

"sending away" and initial loneliness, bonding in groups demanding allegiance, attachment to tradition, subjection to hierarchy and progress upward through it, group ridiculing and punishment of sensitiveness and close relationships, severe sanctions against difference, brutal bodily discipline, and inculcating competitive individualism. (Poynting and Donaldson, 2005: 325)

The systemic violence perspective questions conceptions of violence that make either the private or public sphere responsible for the prevention of violence. For these reasons, we 
consider this perspective to be a useful theoretical starting point for our analysis of violence at Lundsberg School.

\section{Methodology}

The methodological framework of the article is based on theories stemming from Fairclough's critical discourse analysis (CDA). The framework, methods, and data collection are all presented in this section.

\section{$C D A$}

This article is based on a CDA of different educational and media documents concerning cases of violence at Lundsberg School. The choice of this boarding school is motivated by the high level of recurring violence among students at the school. Based on Fairclough $(1992,2000,2001)$, we argue that CDA facilitates an understanding of the dialectical relation between discourse and social practice in the analysis of violence at boarding schools. In this connection, it is argued that CDA facilitates the inclusion of agency in the analysis of violence. Following Fairclough (2000), the interpretation of the empirical data encompasses three dimensions: (a) text analysis (description), (b) processing analysis (interpretation), and (c) social analysis (explanation). In our study, these dimensions correspond to our research questions.

\section{Methods and data selection}

The methodological difficulty of conducting ethnographic studies of violence at boarding schools has also motivated our choice of alternative data collection methods. Therefore, our study is based on non-reactive Internet-mediated data (IMD), which are data that have been gathered on the Internet and therefore have no direct contact with the voices analyzed (British Psychological Association, 2007). A text analysis has also been conducted on the different educational documents and media articles used, all of which include the different actors' descriptions of the violent acts committed at Lundsberg School.

The selected data consist of the following documents: the SSI's records of bullying acts, the SSI website, the boarding school's website, media articles about the violence at the school, letters sent by the school to the SSI and other authorities, and material relating to the social networks at Lundsberg School. A total of 43 documents were analyzed.

In our analysis of the data, we have considered which concepts are most appropriate; as such, the study can be said to be abductive (Psillos, 2011). However, our intention has not been to shape the material to fit certain concepts. On the contrary, we created interpretive grids during the process and as a result decided on the notions of violence as a private good and violence as a public good (Table 1). In our view, these two expressions explain the two discourses that are evident in the material. We have tried to include as many representatives from the various groups as possible in the article.

All the quotations have been translated into English by the authors. Although we argue for the use of alternative data collection methods in research on school violence, we are 
Table I. Material used in the study supporting two different discourses of the violent acts at the boarding school.

Material supporting violence as a private issue

(a) Interviews with the school representatives highlighted in the School Inspectorate's report, (b) statements made by the school's representatives in legal documents, (c) interviews with school representatives in the media, (d) a letter signed by the chairman of the school's student council, and (e) the Swedish court's judgment of the School Inspectorate's decision to close the boarding school
Material supporting violence as a public issue

(a) Interviews with a young person filing a complaint to the School Inspectorate, (b) an interview with the media by a former pupil, (c) the School Inspectorate's own standpoints expressed in reports and on its website, (d) a book written by a former student of the school, and (e) an interview with a former student at another boarding school who was asked to comment on the documented violent acts at Lundsberg School

aware that the use of mediated texts to exemplify the child's perspective can limit the analysis. It is also necessary to stress that from an ethical point of view, the mediated voices of the children and adults interpreted in the material are not expressions of who they are in a static sense, but rather should be seen as vignettes of a specific context and time.

The empirical data analyzed in this study are publicly available and have been published in official documents, on the school's website, and in the Swedish media, which means that consent from individuals did not have to be sought. At the same time, it is important to point out that the names of the children involved in the studied violent cases have been changed to protect their identities. The names of individual authors have been retained only if their material is public and has been published in Swedish media or on websites. However, using the Internet to collect data published in the media and on websites has led researchers to reflect on the fact that individuals can be identified even if their names are removed in the presented research (Markham and Buchanan, 2012). In our study, we reflected on the extent to which the people indicated in the presented data are aware of the fact that according to Swedish law, information expressed in the media and on websites can be used by researchers (cf. British Psychological Society, 2007). Here, we decided to follow earlier research practice for dealing with public material in the analysis of violence in boarding school research (Poynting and Donaldson, 2005); against this background, we have removed the names of the individuals concerned in data published by the media. At the same time, we decided to use digital data despite the possible risk of identification because it was the only data that were available for the study of violence at this particular boarding school. As researchers, we are always required to balance the need to consider the ethical consequences of our selection of data and the need to collect qualified relevant data for the research objectives. The methodological and ethical decisions taken during our research work must therefore be understood as a consequence of our intention to balance these two aspects.

\section{Case I: Violent acts during the period 2009-20 I I}

A pupil in Year 9 at Lundsberg School, here referred to as Oscar, submitted a complaint in 2012 to the Child and School Student Representative, known by the Swedish acronym 
BEO, to the effect that from 2009 to 2010 he had been exposed to violent acts by other pupils at the school. He described a custom whereby younger pupils were encouraged to box or wrestle with each other to entertain the older students, which in one instance had led to a blow to Oscar's head that caused him to fall to the ground. According to Oscar, the entire school, including the authorities, were aware of such occurrences, but regarded them as part of a "toughening up" process. When the BEO received this complaint, the SSI decided to make an unannounced inspection of the school.

The SSI concluded that the school was struggling with serious problems that threatened pupils' safety and the school's learning environment. As a consequence, the Lundsberg School board and authorities were asked to take precautionary measures and to present the results in written form to the SSI before 28 February 2011 (SSI, 2011). Despite the changes that were made and documented, the SSI considered Lundsberg School incapable of dealing with student violence. As a result, it demanded that new safety measures be put in place. In March 2013, a delegation from the SSI visited the school again and found visible proof that it had tried to systematize its anti-violence work but that more work need to be done before the aims could be considered to be satisfactorily fulfilled. Based on promises and the observed direction of the work, the charges were dropped.

\section{Case II: Violent acts in August 2013}

The SSI was informed about another serious violent act at the school in August 2013. This time the victim was a 13-year-old boy, referred to in the following as Lukas. On 24 August 2013, pupils in one of the student residences, Gransäter House, organized a disco. Older students asked the new arrivals, living in the house called Björke, to go to their rooms and pull down the curtains. Shortly after, half a dozen older students visited the younger students' quarters, stopped at one of the rooms, and told the two 13-year-old boys there to lie face down on the floor. One of the boys was then blindfolded. Apparently, these boys had said something demeaning about Gransäter House and were now to be punished. The punishment consisted of branding the letter B (for Björke) on their backs with a steam iron. As a result of this violent incident, the boy called Lukas had to be taken to hospital (SSI, 2013a: 5). On being informed of this case, the SSI set up an investigation that led to a legal process challenging the relationship between the roles of the public and the private in education.

\section{Discourses of violent acts described by different actors}

This section presents and compares the discourses expressed by the Lundsberg School Foundation, the head teacher of the school, the students, and the SSI (Table 2). Two main discourses took form during the analysis process: one in which the private and public spheres were clearly separated and one in which the private and public spheres were addressed in a dialectical manner.

\section{School violence as an issue of a private good}

This discourse was supported by the head teacher, the chairman of the board, a board member, written judicial statements, and a published letter by the chairman of the student 
Table 2. Different discourses concerning violence at boarding schools for the Swedish elite.

\begin{tabular}{|c|c|c|}
\hline Type of discourse & School violence as a private issue & School violence as a public issue \\
\hline \multirow{2}{*}{$\begin{array}{l}\text { Conception of } \\
\text { the education }\end{array}$} & Education as a private good & Education as a public good \\
\hline & $\begin{array}{l}\text { The student hostel is considered a } \\
\text { "family" outside the competence of } \\
\text { the public }\end{array}$ & $\begin{array}{l}\text { The student hostel is considered } \\
\text { within the competence of the public }\end{array}$ \\
\hline $\begin{array}{l}\text { Conception of } \\
\text { childhood }\end{array}$ & $\begin{array}{l}\text { Based on the libertarian conception } \\
\text { of childhood }\end{array}$ & $\begin{array}{l}\text { Based on the republican conception } \\
\text { of childhood as stressing the need to } \\
\text { pay attention to (children's) rights }\end{array}$ \\
\hline $\begin{array}{l}\text { Conception of } \\
\text { violence }\end{array}$ & $\begin{array}{l}\text { Violence is an exclusively private } \\
\text { issue. Violent acts occurring within } \\
\text { the private realm (family) should be } \\
\text { kept and taken care of within the } \\
\text { private realm (family) }\end{array}$ & $\begin{array}{l}\text { Violence as a broader phenomenon } \\
\text { that destroys the borders between } \\
\text { the private and the public spheres. } \\
\text { Private and public are intermixed }\end{array}$ \\
\hline $\begin{array}{l}\text { Agency of the } \\
\text { violent acts }\end{array}$ & $\begin{array}{l}\text { Violence is the product of certain } \\
\text { problematic individuals-those } \\
\text { who break the rules and/or those } \\
\text { bringing violence on themselves }\end{array}$ & $\begin{array}{l}\text { Violence is the result of a social } \\
\text { environment where norms and } \\
\text { values are expressed through } \\
\text { everyday action (speeches, gestures, } \\
\text { body language, etc.) }\end{array}$ \\
\hline $\begin{array}{l}\text { Frequency of the } \\
\text { violent acts }\end{array}$ & $\begin{array}{l}\text { Violence is isolated to certain } \\
\text { occasions and individuals }\end{array}$ & $\begin{array}{l}\text { Systemic violence is part of the } \\
\text { current school culture and cannot } \\
\text { be isolated to certain occasions and } \\
\text { individuals }\end{array}$ \\
\hline $\begin{array}{l}\text { Intentionality in } \\
\text { the violent acts }\end{array}$ & Only intended violence counts & $\begin{array}{l}\text { Even unintended violence can cause } \\
\text { harm }\end{array}$ \\
\hline \multirow[t]{5}{*}{$\begin{array}{l}\text { Conceptions of } \\
\text { the anti-violence } \\
\text { suggested } \\
\text { strategies }\end{array}$} & \multirow{5}{*}{$\begin{array}{l}\text { Opposing violence is about obeying } \\
\text { rules (the school's responsibility } \\
\text { is to inform and uphold explicit } \\
\text { rules). Only explicit norms are } \\
\text { acknowledged (school plans) } \\
\text { Public intervention of the private } \\
\text { school sphere is experienced as } \\
\text { violence against school and students }\end{array}$} & $\begin{array}{l}\text { Opposing violence also means } \\
\text { acknowledging the consequences of } \\
\text { the norms and values expressed in } \\
\text { everyday life }\end{array}$ \\
\hline & & Equally important to acknowledge \\
\hline & & $\begin{array}{l}\text { implicit norms, since enactment } \\
\text { of these norms can cause violence } \\
\text { (hidden curriculum) }\end{array}$ \\
\hline & & $\begin{array}{l}\text { Anti-violence strategies involve } \\
\text { everyone partaking in the } \\
\text { production of social patterns against } \\
\text { the systematization of violent acts }\end{array}$ \\
\hline & & $\begin{array}{l}\text { Public intervention is a legitimate } \\
\text { strategy to stop school violence } \\
\text { when the school is unable to do this }\end{array}$ \\
\hline \multirow[t]{3}{*}{$\begin{array}{l}\text { Intertextual } \\
\text { relationship }\end{array}$} & \multirow{3}{*}{$\begin{array}{l}\text { References to official documents } \\
\text { that argue the lack of competence } \\
\text { of public authorities to intervene } \\
\text { in private sphere (student hostels) } \\
\text { of schools. Limited reference to } \\
\text { human rights legislation }\end{array}$} & $\begin{array}{l}\text { Reference to official arguments that } \\
\text { legitimize public interventions to } \\
\text { prevent school violence }\end{array}$ \\
\hline & & $\begin{array}{l}\text { Reference to official documents that } \\
\text { legitimize the supervision of the } \\
\text { private school sphere }\end{array}$ \\
\hline & & $\begin{array}{l}\text { References to national legislation } \\
\text { against violence and discrimination }\end{array}$ \\
\hline
\end{tabular}


council. The analysis of the data indicates that the violence was regarded as occurring within the exclusive competence of the private sphere. The discourse of violence as $a$ competence of the private sphere was dominant in the descriptions provided by members of the school's staff and pupils/parents. This conception of violence includes a world view in which the categories of private/public and individual/collective are kept separate and arranged hierarchically. Violent acts are presented as taking place within the private realm of the family and having nothing to do with public issues, such as a law protecting children against violence. From this follows that the boarding school's sole responsibility is to punish specific people who commit violent acts.

Furthermore, the descriptions given by the students who were the victims of violence reveal a school culture based on a pattern of certain words, such as family, siblings, loyalty, housemasters, and home. The school was described as a closed family that students need to become part of for their existence. These descriptions declare that in order to be accepted by "the school family" of Lundsberg, younger students must take part in initiation rituals called "proof of existence." Students who refuse to become objects or take part in these "proofs of existence" risked being excluded from "the school family." These descriptions also indicate that such "proofs of existence" are "expected" and "approved" by the housemasters. The normalization of these violent initiations contributed to the reproduction of implicit socialization norms and, consequently, norm deviations. This hidden curriculum often contradicts the explicit norms expressed in political guidelines relating to the right of children not to be subjected to violence. Moreover, this hidden curriculum counteracts the enactment of Lundsberg School's own anti-violence plans and contributes to the normalization of violence in the school's practices (SSI, 2013a: 5-6).

Similarly, according to the BEO (Child and School Student Representative, 2012: 4) report, when asked to describe the incidents, one board member stressed the notion of family and suggested that (this) can be compared to fights among siblings; if someone is irritated by another family member, they usually sort it out themselves. Here, violence is portrayed as something that takes place among the students without the interference of adults. In these descriptions, the students are described as siblings who can sort out fights "by themselves" in the private sphere, in this case the school family.

The notion of being part of a family was also underlined by the chairman of the school's student council (2013), in response to the SSI decision to close Lundsberg: "Being part of Lundsberg School is like attending a camp where each and every one of us becomes part of a big family. We are not ashamed to call ourselves a family" (chairman, Lundsberg School student council, 30 August 2013). The content of the letter describes the school as a protected private sphere that must be kept separate from the intervention of the public sphere (Lundsberg School Website, 2013).

In an appeal to the Administrative Court, the Lundsberg School Foundation (2013) pointed out that it had actively opposed violent treatment at the school by introducing a program of rules and ethical guidelines and informing the students about it. In the report, it is understood that Lundsberg School's anti-violence strategy was based on informing pupils about the school's rules. Thus, by focusing on explicit norms, violence was reduced to a problem caused by isolated dysfunctional individuals who did not follow the school's regulations: 
The Foundation does not agree that the school has not actively tried to prevent violence. In relation to the induction days at the beginning of term on 19-20 August 2013, the students were informed about a programme that included the school's safety plan and rules [...] However, it has been shown that the school's rules have not been followed. (Lundsberg School Foundation, appeal to the Administrative Court 44-2013:4485)

Correspondingly, the chairman of the board described the problem of violence at Lundsberg School as "some pupils" breaking the school rules and that the school had a responsibility to deal specifically with that: "The problem is that some pupils break the rules [...] We have to deal with this" (Dagens Industri, 2013).

Furthermore, a member of the school staff (referring to the incident in August 2013, see Case II above) did not regard the incident as violent treatment because the students' acts were unintentional and not designed to cause harm. He made a distinction between intended and unintended actions and stated that violence means intended actions (SSI, 2013a: 6).

Likewise, a member of the school board pointed out that the incident was not about students deliberately wanting to cause harm and that the victim of the violent act himself had recognized that it was all a big mistake:

What I've heard is that it wasn't a conscious action that was aimed to cause violence to a specific person [...] I understand that the student who was exposed [to the violence] has said it was all a big mistake. (Member of the school board, in the evening newspaper Aftonbladet, 30 August 2013)

Moreover, the same member of the school board described the violent incident as an act performed by certain young individuals making innocent jokes, as boys are apt to do. In this narrative, he described the violent acts in terms of "fun and jokes," "young people who have lost their sense of judgement," "it's more like a boyish prank," and that the boys were now "deeply devastated" (Aftonbladet, 2013a).

At the same time, the community (the majority of the students and school staff) was described as an innocent actor, free from responsibility. In these descriptions, the community became "the good guy," in contrast to the dissenting students or the SSI, who were often described as "the bad guys." Furthermore, this discourse often described the private sphere as a victim of the public sphere's control. Here, the SSI was presented as responsible for violent acts against the Lundsberg School community.

The victimization of the school community was present in the description of the students and school staff as "victims" of the SSI's decision to close Lundsberg School. The term "victims" can be interpreted as the school collectively experiencing this decision as a form of violence against the school and its students. This interpretation was supported by words like "insecurity," "anxiety," and "students without support" to describe the negative impact of the decision on the school. The use of the passive voice in these descriptions is also noteworthy, for example, when the students were described as "victims" of the SSI.

In Lundsberg School's appeal against the SSI's decision to close it down, written in cooperation with its solicitors, it was pointed out that no complaints had been filed after the SSI's last inspection. Hence, it was argued that the violence that took place in August 
2013 should be understood as an isolated event and not part of a recurring pattern. Words like "solitary," "event," "incident" in the singular, "alone," and "isolated" were emphasized in the document (Lundsberg School Foundation, 2013: 5A). There were also examples of a member of the board describing the student filing the complaint, rather than the school, as the perpetrator:

However, he refused to say anything, it was very difficult to get information from him. He was difficult to communicate with and a lot of things were happening around him. The conversations were not documented, which is a fault of the school. The person who filed the complaint is someone with a long history and need of support. (Board member quoted in the SSI's report, 2012: 4)

The analysis shows a language pattern in which the student suffering the violence was portrayed as the person who caused the problem. This can be seen in the use of phrases such as "the pupil had certain difficulties," "he was difficult," "committed rape and burglary," and "he refused," to mention a few examples. While the discourses presented above illustrate an unbridgeable abyss between private and public issues, other discourses described the violence taking place at Lundsberg School as a phenomenon with a dialectical relationship to the private and public spheres.

It is interesting to note that the conception of school violence as a private issue is also present in the Swedish judicial system, as became evident when the SSI's decision to close Lundsberg School as a result of the violent acts reported in 2013 was contested by the boarding school. The appeal was first presented to the Administrative Court and after that to the Administrative Court of Appeal. Both courts rejected the SSI's decision by arguing that the school's residential areas were not within the jurisdiction of the Inspectorate (Administrative Court of Appeal in Stockholm, 2013). This rejection is interesting since activities outside school time are interpreted as a private matter, although they take place in boarding school residences. This ruling also illustrates differences in the various authorities' conceptions of school violence.

\section{School violence as an issue of a public good}

The discourse of school violence as an issue of a public good was supported by a young person complaining about being exposed to violence at Lundsberg School, the School Inspectorate's standpoints as expressed in its reports and on its website, an interview with a former student of the school, and an interview with a former student at another boarding school who was asked to comment on the documented violent acts at Lundsberg School.

Within this discourse, violence is linked not only to the private sphere, where violent acts are seen as isolated individual mistakes, but also to the public sphere. Indeed, violence here directs our attention to the school culture and its systematization and normalization. The strict borders between the private and the public, us and them, formal and informal, and intended and unintended have been crossed, and these entities are now interlinked.

To begin with, a student at Lundsberg, whom we shall call Oscar, actively turned to the publicly funded Child and School Student Representative (the BEO) to ask for help 
in 2012. He felt he was constantly exposed to violence at the school and the only place to turn was to this public organization. Consequently, by sending complaints to the BEO, it can be interpreted that he expressed a hope that the educational authorities would uphold the rights of children. In the SSI report, the student described the violence he experienced as systemic, caused by a school culture (SSI, 2011: 1-4).

On the contrary, the letter from the student council (Metro, 2013) described the school as a "big family" in which members "love each other." However, Hellström (Dagens Nyheter, 2013; see also Hellström, 2014) gives the word "family" a different connotation by describing the students at Lundsberg School as a "chosen group" that is "isolated," where pupils are to be "broken down and then shaped" and "where loyalty to one's family is important." The discourse of violence as an exclusive private issue is intended to make certain categories of students, such as difficult individuals, to be seen as rule breakers or as bringing violence upon themselves and thereby responsible for the violent incidents. In these descriptions, the problem of violence is equated with not following the rules, rather than a phenomenon of school culture.

In an interview about violence at Swedish Boarding Schools in the evening newspaper Aftonbladet (18 September 2013), a former student at another boarding school, Grenna School, underlined the fact that in general, boarding schools differ from other school forms due to their capacity to make violence possible "at night and in the morning," "in the school and student dormitory," and "all the time." Accordingly, no clear line is drawn between the public and private spheres since violent acts can occur everywhere and at any time. According to this reasoning, there is no safe space or time (Aftonbladet, 2013b).

The SSI (2013a) for its part stressed the fact that the students and school staff at Lundsberg School resisted the enactment of the school's values as presented in the formal school plans. The school's informal system of rules was based on a hierarchical world view with different "pecking orders," where the students needed to "work their way up" and learn to "take advantage" of "younger students" as slaves (SSI, 2013a: 4).

In these descriptions, the violence at Lundsberg School was portrayed as systemic and part of everyday school life. In the Aftonbladet interview (2011), a former student maintained that the boarding school culture gave rise to a sense of helplessness: "[y]ou felt completely helpless," and the initiation rites were the worst because the younger students "had to do a lot of degrading things," such having a "broomstick stuck up their butt." According to this former student, it felt as if he "was struggling for survival" (Aftonbladet, 2011).

In addition, the SSI $(2011,2013 a, 2013 b, 2013 c, 2013 d)$ described this normalization of violence as a threat to all the students at Lundsberg School. As above, it was argued that violence could take shape in any way "the staff accept." Although the school could be seen as a place where people "live in a bubble" outside society, the informal rules that existed inside the bubble were real and had consequences for the people involved (SSI, 2011: 4).

\section{An attempt to explain the diversity of discourses in relation to CRC: A closure}

The right of children not to be subjected to violence has been placed in the foreground in this study of two cases of violence at a boarding school in Sweden. The material analyzed consists of reports published by the SSI, statements from students at the school, 
members of the school board, the head teacher, and members of the staff. The material included reports, interviews with the media and the Schools Inspectorate, and letters written by students at the school and by the Lundsberg School Foundation. The purpose of the article has been to investigate how the violent acts at a boarding school in Sweden can be understood and to discuss the possible implications of the different discourses regarding the upholding of children's rights in Sweden.

Two discourses are expressed in the analyzed material that relate to how to deal with and understand the right of children not to be subjected to violence in education. The first discourse puts forth that violence is a challenge that agents in education need to grapple with in private, without interference from the government. The necessity of protecting and honoring the privacy of the school is repeatedly expressed in this discourse by the teachers, students, and other members of staff. From this perspective, the violent acts are private affairs that should not come under the jurisdiction of the SSI. These descriptions can been interpreted as an example of a liberal view of the child (cf. Bentley, 2005) that perceives a child's education as a private family matter that is not subject to state interference. Based on the perception of "education as a private good" (Englund, 1993), the ability to oppose violent acts is considered to stem from within the private sphere, that is, the family, siblings, and housemasters, if the child goes to a boarding school. In this way of reasoning, the students are viewed as family members and not individuals and future citizens who have certain rights and obligations that the public sphere has a responsibility to uphold and protect (cf. Bentley, 2005).

In the second discourse, violence is described as a phenomenon that cannot be reduced to the private realm, but that requires government intervention to protect the rights of the child. This discourse has support in research, which indicates that violence is not only the result of individual mistakes but that there may be a culture that sustains and nourishes it. As such, violence is not generated mainly by "bad," "confused," or "evil" people, but by ordinary individuals with everyday perceptions, actions, values, and norms, but among whom violence sometimes erupts, regardless of good intentions (cf. Gillander Gådin et al., 2013; Kumashiro, 2000; Kumashiro and Ngo, 2007). Representatives of the boarding school constantly referred to the fact that they wanted to change the school environment and make it less violent. Nonetheless, their focus was on strengthening formal guidelines and amending the behavior of certain individuals while ignoring or denying the need to pay attention to the everyday patterns, "jokes," and values that make power hierarchies possible. They emphasize that socialization takes place in the private sphere, in student residences. Reducing brutal acts of socialization to "a family affair" puts students in very vulnerable positions. Furthermore, the victims of violence are presented as "foreign elements" that disturb and attack the traditions of the school houses dormitories and "the family." Consequently, the emphasis of some board members, students, and the head teacher was on the intervention of the SSI as a plot by a society that hates rich people and on the violence taking place at the boarding school as due to pupils who are incapable of following the norms and thus behaving in ways that need to be punished. This tendency to isolate and protect the private sphere from public control can be interpreted as a mechanism of resistance to changes in harmful rituals and traditions that are considered necessary for the socialization of students at Lundsberg School. As Poynting and Donaldson (2005) indicate, the socialization of children at private boarding schools involves the child 
being introduced to a hierarchical system of power that requires allegiance, attachment, and subjection to hierarchy. The children of wealthy parents who attend boarding schools are socialized to compete in a social hierarchical system by means of violent initiation rituals and traditions. The management system of the school, which often consists of actual parents and/or former pupils, can contribute to the reproduction of these socialization practices, including a hierarchical order in which younger students have to obey older students. However, this is not the same as claiming that all children from wealthy families per se are violent and dominating (cf. Young, 1990).

On the other hand, drawing on the writings of the SSI, these violent acts are an abuse of the rights of children and of state laws and guidelines, which implies that they are automatically of public concern. In this context, they intersect the private and public spheres which makes it both possible and necessary for the state to interfere in otherwise purported private matters. Based on a republican conception of the child (cf. Bentley, 2005), educational authorities often appeal to a discourse of defending children's rights when arguing for state intervention. The violent socialization rites that occur in dormitory buildings are considered to be forms of institutionalized and systemic violence that are accepted and promoted by a hierarchical school culture. By considering these acts to be systemic violence (Epp and Watkinson, 1996, 1997), the SSI holds the school staff responsible for them. As such, these brutal forms of socialization radically prevent the work of educational institutions to protect the rights of children as stipulated in Swedish national steering documents and in national and international legislation on children's rights.

The results call for caution in pressing the situation at Lundsberg School into an either/or framework, reducing it to a question that is isolated to solely the private or the public sphere or that relates only to active or passive children or to children as perpetrators or victims. However, by emphasizing the need and ambition to prevent violence in the school, it is impossible to say that every idea and action is equally constructive in achieving this aim. Accordingly, drawing on research on violence, it is clear that violence takes different forms and does not respect the constructed divisions of private and public, conscious and unconscious, intended or unintended action (cf. Epp and Watkinson, 1997; Kumashiro, 2000; Miller, 2002; Volckert, 2002; Young, 1990). In this sense, we argue that the SSI's public intervention in the boarding school's private sphere reflects its striving to protect the rights of children and at the same time recognize private sentiments and interpersonal actions as public concerns.

\section{Acknowledgements}

The authors would like to thank the reviewers in this journal who provided with valuable help to improve the quality of this paper. Many thanks also to the University of Gävle for the opportunity to write this article during Edling's period as Guest Researcher during the academic year 20132014. Thank you both University of Gävle and University of Uppsala for our English language Editors Sue Glower-Frykman and Barbara Rosborg.

\section{Funding}

The author(s) received no financial support for the research, authorship, and/or publication of this article. 


\section{References}

Aftonbladet (2011) Vi blev slagna hela tiden. Available at: http://www.aftonbladet.se/nyheter/article14002510.ab (accessed 29 November 2011).

Aftonbladet (2013a) “Grova misshandeln” ett pojkstreck. Available at: http://www.aftonbladet.se/ nyheter/article17356977.ab (accessed 26 August 2013).

Aftonbladet (2013b) Jakob, 19: "Jag piskades på internatskolan.” Available at: http://bloggar. aftonbladet.se/mobbad/2013/09/jakob-19-jag-piskades-pa-internatskolan/ (accessed 18 September 2013).

Araujo K, Guzmán V and Mauro A (2000) How domestic violence came to be viewed as a public issue and policy object. Cepal Review 70: 137-150.

Benelli SJ (2002) O internato escolar como instituição total: Violência e subjetividade [Boarding school as a total institution: Violence and subjectivity]. Psicologia em Estudo 12(7): 111-122.

Bentley KA (2005) Can there be any universal children's rights? International Journal of Human Rights 9(1): 107-123.

British Psychological Association (2007) Report of the working party on conducting research on the Internet. Guidelines for Ethical Practices in Psychological Research. Available at: http://www.bps.org.uk/sites/default/files/documents/conducting_research_on_the_internetguidelines_for_ethical_practice_in_psychological_research_online.pdf.

Child and School Student Representative (2012) Beslut. [Decision]4 [12] reg. no. 46-2011: 3477.

Dagens Industri (2013) Lundsbergs ordförande: "Viktigt att bra traditioner behålls." Available at: http://www.di.se/artiklar/2013/8/30/lundsbergs-ordforande-viktigt-att-bra-traditionerbehalls/?flik=senaste.

Dagens Nyheter (2013) Interview with Hellström A. Available at: http://www.dn.se/nyheter/sverige/skolorna-ar-en-isolerad-plats/ (accessed 30 August 2013).

Englund T (1993) Utbildning som "public good" eller "private good": Svensk skola I omvandling (Pedagogisk forskning i Uppsala 93). Uppsala: Uppsala universitet, Pedagogiska institutionen.

Epp JR and Watkinson AM (1996) Systemic Violence: How Schools Hurt Children. London; New York: Routledge Falmer.

Epp JR and Watkinson AM (1997) Systemic Violence: Promise Broken. Albany, NY: State University of New York Press.

Garcia J and Monteoliva A (2000) Estudio longitudinal sobre la influencia del tipo de residencia, familiar-escolar, en las transiciones de la escuela al trabajo [Longitudinal study on the influence of the type of residence, family home and boarding school in the transitions from school to work]. Revista de Psicologi'a Social 15(3): 357-367.

Greeff P and Grobler A (2008) Bullying during the intermediate school phase. Childhood 5(1): $127-144$.

Fairclough N (1992) Discourse and Social Change. Cambridge: Polity Press.

Fairclough N (2000) Discourse, social theory and social research: The discourse of welfare reform. Journal of Sociolinguistics 4: 163-195.

Fairclough N (2001) The dialectics of discourse. Textus XIV 2: 231-242. Available at: http://www. lancaster.ac.uk/ias/profiles/norman-fairclough.

Gillander Gådin K, Ahlgren C and Gaby W (2013) School health promotion to increase empowerment, gender equality and pupil participation: A focus group study of a Swedish elementary school initiative. Scandinavian Educational Research 57(1): 54-70.

Hamby S and Grych J (2013) The Web of Violence Exploring Connections Among Different Forms of Interpersonal Violence and Abuse. New York; London: Springer Dordrecht Heidelberg. 
Hellström A (2014) Att vara utan att synas. Om riksinternaten Lundsberg, Sigtuna och Gränna [To Be Without Being Visible. About the Boarding Schools Lundsberg, Sigtuna and Grenna]. Stockholm: Månpocket.

James A and James A (2004) Constructing Childhood: Theory, Policy and Social Practice. New York: Palgrave Macmillan.

Kumashiro K (2000) Towards a theory of anti-oppressive education. Review of Educational Research 72(1): 25-53.

Kumashiro K and Ngo B (2007) Six Lenses for Anti-Oppressive Education: Partial Stories Improbable Conversations. New York: Peter Lang.

Lundsberg School Foundation (2013) A Formal Appeal to the Administrative Court. Stockholm: Förvaltningsrätten, $\mathrm{nr}$ 44-2013:4485.

Lundsberg School Website (2013) Administrative Court of Appeal I in Stockholm. Dom. Mål nr 6413-6415-13. Available at: http://www.lundsbergsskola.se/index.php?id=66 (accessed 30 August 2013).

Markham A and Buchanan E (2012) Ethical Decision-Making and Internet Research Recommendations from the AoIR Ethics Working Committee (version 2.0). Available at: http://aoir.org/reports/ethics2.pdf.

Metro (2013) Letter from the Head of the Students Council at Lundsberg School. Available at: http:// www.metro.se/nyheter/eleverna-vi-kanner-oss-valdtagna/EVHmhB!CicL6qNGEhRJM/ (accessed 30 August 2013).

Miller A (2002) For Your Own Good: Hidden Cruelty in Child-Rearing, and the Roots of Violence, 5 th edn. New York; Frankfurt: Suhrkamp Verlag.

Parkes J (2007) The multiple meanings of violence. Children's talk about life in a South African neighbourhood. Childhood 14(4): 401-414.

Partridge S (2007) Trauma at the threshold: An eight year-old goes to boarding school. Attachment 1(3): $310-313$.

Partridge S (2012) Boarding school syndrome. British Journal of Psychotherapy 28: 129-131.

Pfeiffer J and Pinquart M (2014) Bullying in German boarding schools: A pilot study. School Psychology International 35(6): 580-591.

Poynting S and Donaldson M (2005) Snakes and leaders: Hegemonic masculinity in ruling-class boys' boarding schools. Men and Masculinities 7(4): 325-346.

Prop. (2009/10:232) Strategies för att stärka barnets rättigheter $i$ Sverige [Strategies to strengthen the rights of the child in Sweden]. Socialdepartmentet [Socialdepartment]. Available at: http://www.regeringen.se/sb/d/12168/a/148701.

Psillos S (2009) An explorer upon untrodden ground: Peirce on abduction. In: Hartmann S and Woods J (eds) Handbook of the History of Logic, vol. 10. Amsterdam: Elsevier BV: 117-151.

Quennerstedt A (2011) The construction of children's rights in education-A research synthesis. International Journal of Children's Rights 19: 661-678.

Schaverien J (2011) Boarding school syndrome: Broken attachments a hidden trauma. British Journal of Psychotherapy 27(2): 138-154.

SFS (2008:567) Discrimination Act.

SFS (2010:800) The New Education Act-For knowledge, choice and security. Available at: http:// www.riksdagen.se/sv/Dokument-Lagar/Lagar/Svenskforfattningssamling/Skollag-2010800 sfs-2010-800/?bet=2010:800\#K1.

Standish E (2011) Boarding school syndrome. British Journal of Psychotherapy 27: 417-419.

Swedish Schools Inspectorate (SSI) (2011) Beslut för grundskola och gymnasieskola efter tillsyn av Lundsbergs skola i Storfors kommun Dnr 49-2011:5192 [Decision for Elementary School and Upper Secondary High School after a Supervision of Lundsberg School in Storfors Municipality]. 
Swedish Schools Inspectorate (SSI) (2013a) Beslut. Dnr 44-2013:4485 (accessed 28 August 2013).

Swedish Schools Inspectorate (SSI) (2013b) Uppföljning av föreläggande vid vite, Lundsbergs skola i Storfors kommun. Beslut. Dnr 44-2011:5192 1(12) [A follow up of a case concerning vite, Lundsberg School in Storfors Municipality] (accessed 5 April 2013).

Swedish Schools Inspectorate (SSI) (2013c) Tillsyn-granskning/Fragor-och-svar-med-anledning$a v$-The Swedish School Inspections-beslut-att-stanga-Lundsbergs-skola. Available at: www. skolinspektionen.se (accessed 23 March 2014).

Swedish Schools Inspectorate (SSI) (2013d) Överlämnande av överklagande samt yrkande om inhibition till Förvaltningsrätten i Stockholm. Beslut 2012-08-05. Dnr 82-2013:4591 1(2) [A Submission of an Appeal as Well as an Inhibition to Administration Law].

United Nations (1989) Convention on the rights of the child. General Assembly resolution 44/25, 20 November. U.N. Doc. A/RES/44/25. Available at: http://www.ohchr.org/en/professionalinterest/pages/crc.aspx (accessed 3 April 2014).

Volckert J (2002) Det traumatiska arvet. Om smartens förvandling till våld [The traumatic heritage]. In: Bogrén M and Volckerts J (eds) Våldets psykologi [The Psychology of Violence]. Stockholm: Prisma: 13-34.

Young IM (1990) Justice and the Politics of Difference. Princeton, NJ: Princeton University Press. Zindi F (1994) Bullying at boarding school: A Zimbabwe study. Research in Education 51(1): 23-23. 